\title{
DAUGIAKALBYSTĖS SKATINIMO VEIKSNIAI MOKANT KARIŪNUS UŽSIENIO KALBŲ LKA
}

\author{
Doc. dr. Dileta Jatautaitė \\ Generolo Jono Žemaičio Lietuvos karo akademija
}

\begin{abstract}
Anotacija. Straipsnyje gvildenama problema, susijusi su veiksniais, skatinančiais kariūnu daugiakalbystę mokantis universitetinèse studijose Generolo Jono Žemaičio Lietuvos karo akademijoje (toliau - LKA). Vienas iš pagrindiniu veiksniu, skatinančiu kariūnus mokytis užsienio kalbu, yra motyvacija, t. y. kodèl kariūnai renkasi vienas ar kitas užsienio kalbas, kas lemia ju pasirinkima. Žinant pagrindinius veiksnius, skatinančius kariūnus judèti sèkmès link, galima sutelkti visas individo galias ir energija pasiekti tiksla - II mokèjimo lygi pagal (STANAG 6001) NATO kalbu mokejimo standartus. Straipsnyje pateikiamas tyrimas, kurio rezultatai parodè pagrindines priežastis, kodèl kariūnai mokosi užsienio kalbu ir kas juos motyvuoja ju mokytis. Taip pat labai svarbu parodyti, kaip kalbu mokymasis mokykloje koreliuoja su užsienio kalbos pasirinkimu LKA. Straipsnyje pateikiamos išvados, analizuojami ir apibendrinami tyrimo rezultatai, kurie gali büti naudingi tobulinant užsienio kalbu mokyma(si), plečiant ir gilinant žinias apie mokymosi motyvaciją.
\end{abstract}

Pagrindiniai žodžiai: mokymosi motyvacija, užsienio kalbos mokymosi motyvacija, daugiakalbystè, mastymas, psichinès savybès, kognityvinis procesas.

Ivadas. Daugiakalbystę išsamiai tiria sociologai, psichologai, lingvistai, pedagogai ir kitų sričių specialistai. Ši tema yra labai aktuali, nes Lietuvos krašto apsaugos sistemoje nèra tiriami veiksniai, lemiantys užsienio kalbų pasirinkimą ir motyvaciją mokytis vienų ar kitų kalbų. Taip pat nẻra sukurta praktiné, teorinė ir tyrimais pagrịsta paradigma, kuri remtųsi naujausiais mokslo pasiekimais ir būtų sudaryta iš teorinio - praktinio modelio, padedančio spręsti intensyvų ir efektyvų daugiakalbystės mokymą(si) ir išmokimą. LKA Užsienio kalbų katedroje (toliau - UKK) vyksta intensyvus moksliškai grindžiamas kariūnų užsienio kalbų mokymas ir atliekami tyrimai. Užsienio kalbų mokymas (didaktika) ir moksliniai tyrimai, remiantis psichologiniais (motyvacija, atmintis, emocijos, mąstymas ir kt.) arba psichoedukologiniais (pedagoginiais ir androgoginiais) pagrindais, yra jau seniai ir plačiai vykdomi Lietuvos (VU, VDU, ŠU, LEU, KTU ir kt.) mokslininku - prof. L. Jovaišos, prof. S. Kregždès, prof. V. Šerno (glotoedukologijos, arba daugiakalbystès, Lietuvoje pradininkas), dr. D. Masaitienès (VDU), prof. M. Teresevičienès (VDU), prof. R. Minkutès (KTU) ir daugelio kitų, apgynusių disertacijas ir dirbančių šioje srityje. 
Šio straipsnio tikslas yra išanalizuoti veiksnius, skatinančius daugiakalbystę mokant kariūnus užsienio kalbų, atlikti tyrimą, kuris padètų nustatyti, kodèl kariūnai renkasi vienas ar kitas kalbas ir kas juos motyvuoja jas rinktis.

\section{Tyrimo uždaviniai:}

- išanalizuoti veiksnius, skatinančius kariūnus mokytis užsienio kalbų;

- nustatyti, kas motyvuoja kariūnus rinktis vienas ar kitas kalbas LKA.

Tyrimo problema ir aktualumas. Užsienio kalbų mokymosi motyvaciją lemia individo kalbų mokymosi patirtis, pasiekti rezultatai, sèkmè ir interesai. Kiekvienas besimokantis asmuo turi savitą mokymosi procesą, individualią mokymosi istoriją, kalbos mokymosi biografiją ir patirtį (Fremdsprache Deutsch. Motivation, 2002). Besimokantys individai, turintys asmeninę kalbų mokymosi patirtį, teigia, kad užsienio kalbų mokytis įdomu, naudinga, prasminga (Šernas, 2006). Kuo didesnè ši minèta patirtis, tuo lengviau mokytis kalbų. Formuojant mokymosi motyvaciją svarbi mokymosi objekto pritaikymo perspektyva - užsienio kalbos praktinis pritaikymas.

Lietuva yra NATO ir Europos Sajungos narè, todèl Lietuvoje užsienio kalbų mokymas(is) turi atitikti NATO STANAG 6001 (norminis dokumentas) ir ES „Europass" (Europos Sajungos norminiai dokumentai) standartus.

Europos Komisija 2008 m. rugsèjo 18 d. pasiūlè daugiakalbystę įtraukti ị Europos Sajungos (ES) politikos, mokslo, kultūros ir ekonomikos sritis pagal priimtą komunikatą „Daugiakalbystė - Europos turtas ir bendras rūpestis“. ES Taryba yra taip pat prièmè rezoliuciją dèl Europos daugiakalbystès strategijos, o Lietuvos Respublikos Seimo Švietimo, mokslo ir kultūros komitetas ir Informacinès visuomenès plètros komitetas ėmèsi iniciatyvos analizuoti daugiakalbystès plètros klausimą šiuolaikinių technologijų sąlygomis ir pasiūlè Lietuvos aukštosiose mokyklose skatinti daugiakalbystę pasinaudojant naujausiais glotoedukologijos pasiekimais.

Problema. Daugiakalbyste yra suprantama kaip sudètingas vyksmas, kuris reikalauja daug lingvistinių, didaktinių ir psichologinių žinių apie kalbų formavimąsi, kognityvinius jų konstravimosi procesus ir kitų psichinių savybių funkcionavimo svarbą. Todèl yra būtinybè šiame kontekste skatinti daugiakalbystę per autodidaktiką, metakognityvinị kariūno mąstymą, ịtraukti kuo daugiau pojūčių ir ugdymo pagrindais sukurti teigiamas emocijas skatinančią aplinką, nes tik saugioje aplinkoje, kai nejaučiama grèsmè ir baimè, besimokantis individas gali būti motyvuotas sèkmingai mokytis ir išmokti daug kalbų.

Tyrimų objektas - daugiakalbystès skatinimo veiksniai mokant kariūnus užsienio kalbų. 


\section{Tyrimo metodai:}

Teoriniai: mokslinès pedagoginės-psichologinès, socialinès literatūros analizè.

Empiriniai: anoniminė anketinè apklausa raštu, siekiant ištirti kariūnų kalbų pasirinkimą; mokslininkų darbų analizė; dokumentų analizė; interviu, pokalbis, statistinè duomenų analizè, anketa. Anketinių duomenų analizei naudota SSPS programa (Statistical Package for the Social Sciences); tyrimo duomenys, kurie apdoroti taikant kiekybinès ir kokybinės analizès metodus; „Windows Microsoft Word“ ir „Windows Microsoft Excel“" programos tyrimo metu padejo gauti duomenis, juos apdoroti, sisteminti ir grafiškai pavaizduoti.

\section{Svarbiausi kariūnų kalbų pasirinkimo veiksniai mokantis LKA}

Yra daug veiksnių, kurie lemia kariūnų vienų ar kitų kalbų pasirinkimą mokantis LKA. Vienas iš pagrindinių veiksnių - Lietuva yra NATO ir Europos Sajungos narè, todėl Lietuvoje užsienio kalbų mokymas turi atitikti NATO ir ES standartus. Kadangi anglų kalba yra pagrindine NATO kalba, krašto apsaugos sistemoje pagrindinis dèmesys skiriamas anglų kalbos mokymui(si). Vadinasi, anglų kalba yra tapusi pagrindine karininkų ir civilio personalo darbo kalba Lietuvos krašto apsaugos sistemoje, t. y. gynybos ir pasipriešinimo kalba.

Nuo tinkamai taikomos kalbų mokymo(si) didaktikos priklauso efektyvus ir darnus Lietuvos krašto apsaugos sistemos funkcionavimas, veiksmingas ịsipareigojimų NATO, ES ir kitiems partneriams vykdymas laiku.

Anglu kalba yra tapusi darbo kalba ir be II kalbos mokejjimo lygio šiuolaikinis karininkas negali pilnavertiškai ir efektyviai atlikti savo kasdienių pareigu NATO štabuose, logistikos, žvalgybos tarnybose ir kt. Kadangi KAS dirba nauja karininkų karta, kuri natūraliai ịvaldè anglų kalbą, jai jau nepakanka mokèti tik anglų kalbą, nes keičiasi geopolitinè situacija pasaulyje, iškilo naujos grèsmès (konfliktas Ukrainoje), išsiplète konfliktu geografija (Malis Afrikoje). KAS karininkai vyksta dirbti instruktoriais, patarejais ar vykdo kitas misijas ir todèl jiems iškilo būtinybe įvaldyti dar vieną užsienio kalbą, pavyzdžiui, rusų ar prancūzų. Atitinkamai keičiasi ES kalbų mokèjimo ir mokymo(si) politika - vienas iš ES komisijos keliamų 2014-2020 metų tikslų, kad iki 2020 metų 80 \% ES piliečių turi mokèti dvi užsienio kalbas.

Todèl reaguodama ị būtinumą rengti visapusiškai išprususị karininką, mokantị mažiausiai 2 užsienio kalbas, UKK pertvarkè užsienio kalbų mokymo politiką ir nukreipé savo edukologinị potencialą ị daugiakalbystės skatinimą, kaip svarbiausią užsienio kalbą paliekant anglų kalbą, nes be II kalbos mokèjimo lygio pagal UKK parengtą pasiekimų testą kariūnui negali būti suteiktas leitenanto laipsnis.

Siekdami II lygio, kariūnai privalo lavinti visų keturių komunikacinès veiklos rūšių igūdžius, plèsti kasdienès ir profesinès veiklos sričių žodyną, gebėti atlikti vidutinio sudètingumo tiek kalbos supratimo, tiek kūrybines kalbos užduotis (pa- 
gal tarptautinę klasifikaciją tai atitiktų „Intermediate“, pagal Bendruosius Europos kalbų metmenis B1-B2 arba SLP 2222 pagal ND6001 lygi). Toks kalbos mokèjimo lygis turi atitikti kasdienius profesiniam kalbos vartojimui keliamus reikalavimus.

Kariūnai, kurie bendrojo lavinimo mokykloje mokèsi anglų kalbos, po I kurso II semestro privalo pasiekti bazini anglų kalbos lygị. Po II kurso IV semestro kariūnai privalo pasiekti II lygi, kuris yra privalomas pagal krašto apsaugos ministro $2010 \mathrm{~m}$. spalio $1 \mathrm{~d}$. Nr. V-1045 ir $2011 \mathrm{~m}$. spalio $13 \mathrm{~d}$. Nr. V-1159 ịsakymus leitenanto laipsniui gauti.

Jei kariūnai nepasiekia II lygio, jiems suteikiamas Bazinis kalbos lygis ir tokiu būdu jie ịgyja pagrindinių anglų kalbos žinių ir įgūdžių (pagal tarptautinę klasifikaciją tai atitiktų „Elemetary“, A1 pagal Bendruosius Europos kalbų metmenis arba SLP (angl. Standardized Language Profile) 1111 pagal ND6001 lygi), todèl turèdamas Bazinị (surinkęs nemažiau $65 \%$ iš testo) lygị kariūnas gebès tik susikalbèti anglų kalba kalbančioje aplinkoje. Profesiniam vartojimui toks kalbos mokejjimo lygis yra nepakankamas, todèl jiems sudarytos galimybès mokytis anglu kalbos fakultatyvo forma ir toliau siekti numatyto II kalbos lygio. Baigęs anglų kalbos fakultatyvo modulį, jis pakartotinai gali laikyti PTK (kariūnų pasiekimų testą) ir tokiu būdu siekti II lygio pagal numatytą būrio vado, turinčio leitenanto laipsnį, kvalifikaciją.

Kariūnams, nesimokiusiems anglų kalbos iki įstojimo ị LKA, užtenka pagal PTK standartus pasiekti bazinị (surinkti nemažiau $65 \%$ testo taškų) anglų kalbos lygi leitenanto laipsniui gauti. Jiems taip pat yra sudarytos galimybės tobulinti anglų kalbos žinias ir siekti bazinio anglų kalbos lygio fakultatyvo mokymo(si) forma.

Nuo 2015 m. LKA yra taikoma nauja griežta tvarka kontroliuojant kariūnų, siekiančių II lygio pagal krašto apsaugos ministro $2010 \mathrm{~m}$. spalio $1 \mathrm{~d}$. Nr. V-1045, 2011 m. spalio 13 d. Nr. V-1159 įsakymus ir 2015 m. liepos 14 d. ịsakymu Nr. V-696 „Dèl Užsienio kalbų mokymo poreikių nustatymo, atrankos ị užsienio kalbų kursus, užsienio kalbų mokymo ir testavimo krašto apsaugos sistemoje tvarkos aprašo patvirtinimo" patvirtintą aprašą, mokymosi procesą.

Pagal ši aprašą ir LKA studijų programas, kurios yra akredituotos Studijų kokybès vertinimo centro (SKVC), taip pat yra numatyta, kad po II kurso II anglų kalbos lygi pasiekę kariūnai renkasi antrą užsienio kalbą. UKK kariūnai be anglų gali rinktis prancūzų, vokiečių ir rusų kalbas.

\section{Motyvacija yra pagrindinis veiksnys, skatinantis kariūnus mokytis}

\section{kalbụ}

Užsienio kalbų mokymosi motyvacija yra pagrindinis veiksnys, skatinantis mokytis kalbų ir jų išmokti; be motyvacijos neįmanomas joks kognityvinis procesas, būtinas mąstyti, ịsiminti, suvokti, susikaupti. Nustatyta, kad bendrojo intelekto ir mokymosi motyvacijos koreliacija paprastai svyruoja apie 0,50. Kai kurie kiti tyrimai parodè, jog koreliacija gaunama net iki 0,80 . Didelè koreliacija tarp 
mokymosi pasiekimų, motyvacijos ir kognityvinių gebejjimų dažnai laikoma vienu iš reikšmingiausių tyrimo instrumento validumo argumentų. Šiuo pagrindu galima teigti, kad yra bendra mokslininkų nuomonė formuluojant tris pagrindinius motyvacijos veiksnius mokantis kalbų: žmogaus veiklos tikslingumą, pastangas ir kryptingumą siekiant užsibrežtų tikslų (Rheinberg, 2000). Be abejonès, bet kurio besimokančio individo rezultatai bus žymiai geresni, jei jis be intelektiniu gabumų turès dar ir teigiamą nusistatymą mokytis. Pavyzdžiui, vienas žymiausių šios srities mokslininkų ir motyvacijos teorijos pradininkas R. C. Gardner motyvaciją apibūdina kaip pastangas, tikslo siekimą mokant kalbos ir tinkamą požiūrị i kalbos mokymąsi (Gardner, R. C. \& W. Lambert, 1972).

Profesorius L. Jovaiša motyvaciją (lot. motus - proto veikimas, minties skrydis; pranc. motif - skatinamoji priežastis, veiksmo pagrindas) aiškina, kaip ,psichofiziologinị procesą, reguliuojantị asmenybès veiklą ir santykius su aplinka motyvų kaitos pagrindu“ (2007, p. 172). G. Butkienè ir A. Kepalaitè (1996, p. 225) aiškina motyvaciją, kaip „veiksmų bei elgesio žadinimą ir skatinimą, vykstantị žmogaus psichikoje“; Gage ir Berliner (1994, p. 263) motyvaciją supranta per „poreikius, interesus, vertybes, pažiūras, siekius ir polinkius“; Dörnyei (1998, p. 121) motyvacijoje įžvelgia ,procesą, kurio metu atsiranda stipri jèga, skatinanti veiklą, kol nebus pasiektas užsibrèžtas tikslas, net ir atsiradus kitai jègai, bandančiai nuslopinti pirmają", M. Williams ir R. L. Burden (1997) skirsto šiuos veiksnius ị vidinius, susijusius su kognityvinèmis, metakognityvinèmis, emocinèmis einančio mokslus galiomis, ir išorinius, kurių reikètų ieškoti besimokančio asmens socialinejje aplinkoje.

Socialinio konstruktyvizmo atstovai M. Williams ir R. L. Burden (1997) motyvaciją skirsto ị vidinę, susijusią su kognityvinèmis, metakognityvinèmis, emocinėmis einančio mokslus galiomis, ir išorinę, kuri išplaukia iš socialinès aplinkos. Šie motyvacijos veiksniai yra būdingi ir užsienio kalbos mokymosi motyvacijai, kurią tikslinga aptarti išsamiau.

Užsienio kalbų mokymosi motyvaciją lemia individo kalbų mokymosi patirtis, pasiekti rezultatai, sèkmė ir interesai (Fremdsprache Deutsch. Motivation, 2002). Kiekvienas asmuo, kuris mokosi, turi savo išdirbtą mokymosi metodiką, individualią mokymosi patirtį, kalbos mokymosi evoliuciją. Tie, kurių užsienio kalbų mokymosi patirtis yra sẻkminga, dažnai skatinami sékmès yra motyvuoti iš vidaus. Tai dar paspartina mokymąsi ir padaro ši procesą prasmingą, įdomų ir turiningą. Kuo didesnè sékminga patirtis, tuo lengviau mokytis kalbų. Žinoma, besimokantis individas ne visada būna pats motyvuotas, tad jam padeda išorinès paskatos; jei lydi sékmé, ilgainiui išorinè motyvacija perauga ị vidinę, o tada mokymasis pavirsta džiaugsmu, kuris pagreitina kalbos išmokimą. Formuojant mokymosi motyvaciją svarbi mokymosi objekto pritaikymo perspektyva yra užsienio kalbos praktinis pritaikymas, pavyzdžiui, kai kariūnai turi galimybes vykti ị užsienio šalis pagal „Erasmus“ programą arba pagal karinių aukštujų mokyklų bendradarbiavimo ir mobilumo programas.

Siekiant išsiaiškinti, kodèl LKA kariūnai renkasi vienas ar kitas kalbas, kas 
juos motyvuoja rinktis jas, buvo atliktas žvalgomasis tyrimas. Šiuo tikslu 2015 metais panaudojant anoniminę anketą buvo apklausti 45 respondentai. Apklausoje dalyvavo 62 LKA kariūnai. Anketoje buvo pateikti tokie klausimai: „Kodèl mokausi anglų kalbos?“, „Kodėl mokausi rusų kalbos?“", „Kodėl mokausi prancūzų kalbos?“ Leista pasirinkti vieną iš trijų atsakymų: „Aš noriu“, „Reikalaujama“, „Neaišku. Gal prireiks". Paskui buvo siūloma trumpai motyvuoti vieną ar kitą pasirinkimą. Mūsų atlikta apklausa parodè, jog žymi dauguma tų, kurie mokosi, - 35 asmenys, arba $78 \%$, mokèsi anglų kalbos todèl, kad norèjo. 9 (20\%) LKA kariūnai teigè, kad jie mokèsi anglų kalbos tik dèl to, kad iš jų reikalaujama. Vos 1 (2\%) LKA kariūnų atsakè, jog „Gal prireiks“. Vadinasi, galime teigti, kad dauguma LKA kariūnų supranta anglų kalbos mokymosi būtinumą ir jaučia vidinę motyvaciją. Tik $20 \%$ kariūnų yra motyvuojami iš išorès ir atsakè, kad jiems tai gali būti svarbu ateityje, t. y. gal prireiks. Tai galime matyti iš 1 pav..

\section{Kodèl kariūnai mokosi anglų kalbos}

$78 \%$ todèl, kad norejo

$20 \%$ todèl, kad reikalavo

$2 \%$ gal prireiks

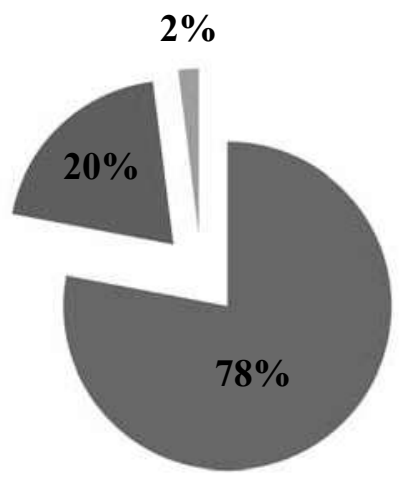

1 pav. Kodèl kariūnai mokosi anglų kalbos

Tačiau daugelio tų pačių respondentų duomenys kardinaliai skyrèsi, kai jie buvo klausiami apie mokymosi motyvaciją kitų kalbų atžvilgiu. Iš anketinès apklausos paaiškejjo, kad kitomis užsienio kalbomis (vokiečių ir prancūzų) jie mažiau domejosi. Tačiau jų paaiškinimai priešiškumo joms neparodè. Dauguma respondentų teigè, jog paprasčiausiai nematė prasmès jų mokytis ir apsikrauti nereikalinga informacija. Be to, dauguma apklaustujjų nematè praktinio būtinumo jų mokytis, nes, jų manymu, pakanka mokèti anglų arba rusų kalbą, kad būtų galima praktiškai realizuoti savo poreikius ir norus siekti karjeros krašto apsaugos sistemoje. Kiti respondentai teigè, kad jų nenorą mokytis vokiečiu ir prancūzų kalbų lėmė kurso apkrovimas nenaudingais dalykais, mažas, t. y. 3, kreditų skaičius, skirtas užsienio 
kalbų pratyboms ir tai, kad jie paprasčiausiai nespejja. Dalis nenorinčių mokytis kaltino kurso perkrovimą gramatikos taisyklemis, kurias „,mokèsi tik todèl, kad reikejjo gauti geresni pažymị ar stipendijąa“. Labai įdomūs rezultatai buvo gauti apklausiant dèl rusų kalbos mokymosi. Rusų kalbos kaip antrosios užsienio kalbos mokymosi svarbą ịvertino net $96 \%$ respondentų. $51 \%$ iš jų teigè, jog rusų kalbą svarbu mokytis, nes ja kalbama priešiškai nusiteikusioje valstybeje, o $37 \%$ atsakè, jog rusu kalba svarbi, nes Rusija yra didžioji mūsų kaimynė; $12 \%$ atsakè, jog užtenka tik dviejų (anglų ir rusų) kalbų, kad užsienyje galima būtų apskritai susikalbèti. Tai galime matyti iš 2 pav.

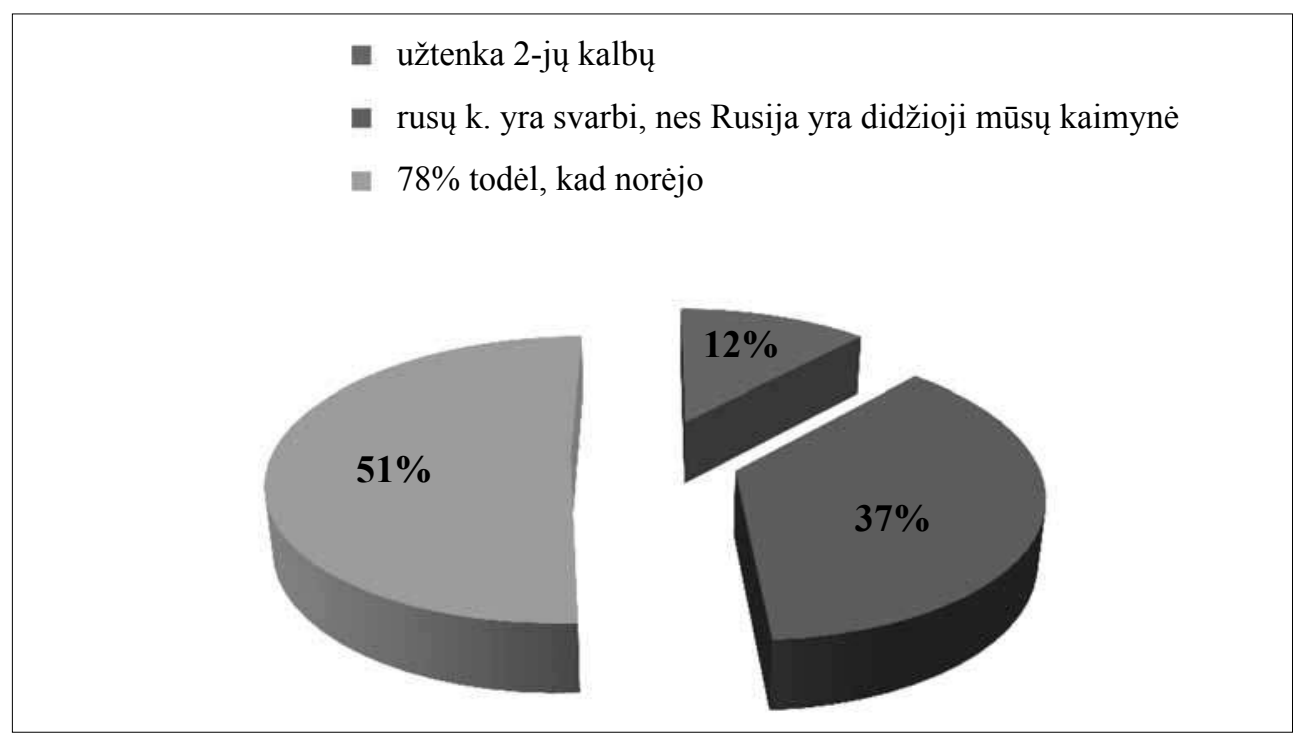

2 pav. Kodèl kariūnai rinkosi rusų kalbą

Labai įdomiai su LKA tyrimais siejasi Statistikos departamento duomenys. Pasak Statistikos departamento, 2010 metais Lietuvoje anglų kalbą mokančiu gyventojų dalis išaugo iki 30,4 \% (16,9\% - $2001 \mathrm{~m}$.), rusų kalbą moka $63 \%$ gyventojų, lenkų $-8,5 \%$, vokiečių $-8,3 \%$. Kolegijų ir universitetų studentai taip pat dažniausiai renkasi mokytis anglų kalbą. Asmenys, besimokantys anglų kalbos, sudaro $30,6 \%$, vokiečių $-4 \%$, rusų $-2,4 \%$, prancūzų $-1,6 \%$. III kurse paprastai kariūnai renkasi rusų kalbą, nes po IV semestro jie turi būti pasiekę II anglų kalbos lygị pagal PTK. Todèl turèdami galimybę rinktis, dauguma renkasi rusų kalbą ( $83 \%)$. Vokiečių (7 \%) ir prancūzų (4 \%) kalbų mokosi mažiausiai. Anglų kalbą dažniausiai priversti mokytis tik tie, kurie nepasieke II PTK lygio (3 pav.). 


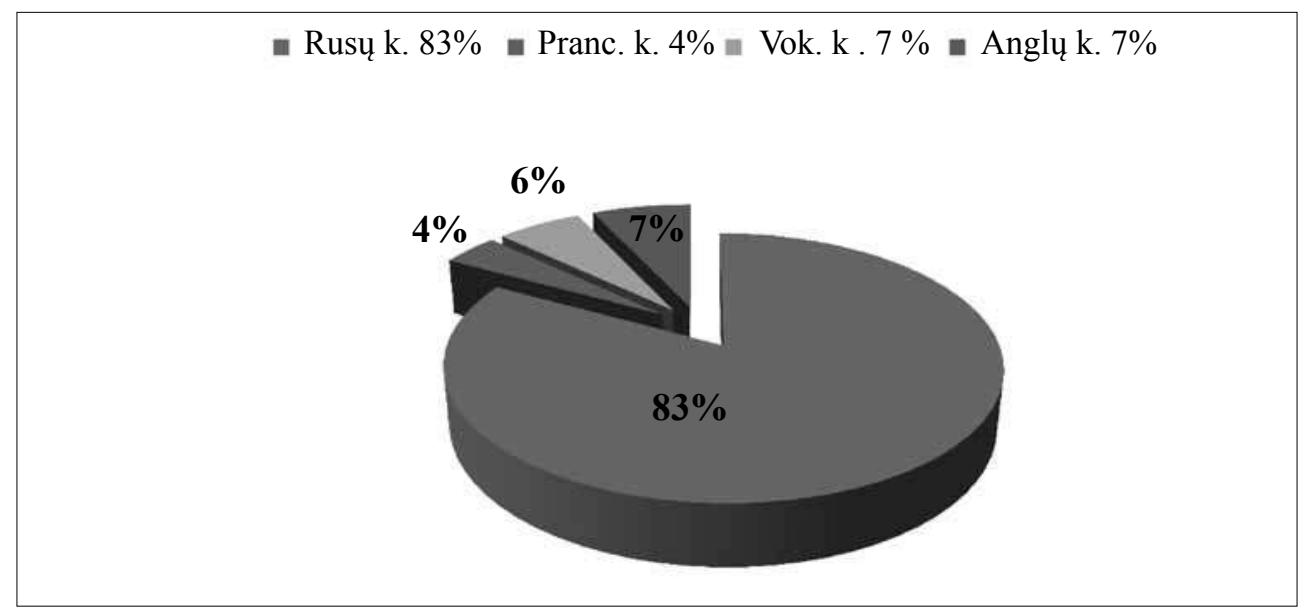

3 pav. Kariūnų užsienio kalbų pasirinkimas III kurse

Pasak Eurobarometro, 28 proc. lietuvių mano, kad vokiečių kalba būtų naudinga kaip viena iš dviejų užsienio kalbų. Tačiau praktika rodo, kad vokiečių kalba pamažu nyksta iš mokyklų. 2010-2011 mokslo metais ši kalba Kauno mokyklose beveik nemokyta. Tai keista, nes Vokietija yra ekonomiškai stipriausia šalis Europoje. Tik pastaraisiais metais pamažu Lietuvos gyventojai vèl pradejo mokytis vokiečių kalbos komerciniuose kursuose, nes atsivèrè Vokietijos darbo rinka. LKA keletą metų vokiečių kalbos niekas nesirinko. Tik 2015 m. LKA 6 kariūnai pasirinko vokiečių kalbą ir tik dèl to, kad jos mokèsi mokykloje.

Vadinasi, be motyvacijos, kognityvinių, lingvistinių, didaktinių ir psichologinių veiksnių, egzistuoja, visų pirma, kalbų pasirinkimo problema, apsunkinanti daugiakalbystės skatinimą Lietuvoje. Pavyzdžiui, nors Lietuvoje vis didejja skandinavų, italų, ispanų, turkų ir Rytų (japonų ir kinų) kalbų poveikis, anglų kalba išlieka dominuojanti. Apie $90 \%$ moksleivių mokosi anglų kalbos, o pirmose klasėse daug kur net iki $99 \%$. Kaip rodo ES statistika, Lietuvos gyventojai daugiausiai iš visų Europos šalių renkasi anglų kalbą. Beveik 90 \% visų gyventojų mano, kad anglų kalba - ekonominiais, politiniais, moksliniais aspektais naudingiausia užsienio kalba globaliame pasaulyje. Visų kariūnų nuomone, kalbos mokèjimas yra būtinas, nes Lietuva yra Europos Sajungos ir NATO narè, LKA yra puikios galimybès studijuoti užsienyje, yra taip pat puikios galimybès gauti gerai apmokamą darbą ne tik Lietuvoje, bet ir užsienyje. Akivaizdu, kad poreikis ir noras kyla iš praktinio būtinumo.

Todèl norèdama išsiaiškinti, kaip besimokančių LKA kariūnų kalbų pasirinkimą lemia kalbų mokymasis mokykloje, UKK atliko tyrimą ir nustate, kaip koreliuoja kalbų pasirinkimas LKA ir mokymasis mokykloje.

Gauti rezultatai parode, kad mokymąsis mokykloje ir LKA tiesiogiai koreliuoja. Užsienių kalbų tolesnį mokymosi pasirinkimą LKA lemia tos užsienio kalbos, kurių kariūnas mokèsi mokykloje. Iš pateiktų ịstojusiųjų i LKA duomenų 
galime matyti, kad jie mažai kuo skiriasi nuo Statistikos departamento duomenų (4 ir 5 pav.). Vadinasi, dauguma kariūnų, įstojusių ị LKA, toliau tęsia anglų kalbos mokymąsi po mokyklos baigimo. Mažai kas iš kariūnų renkasi tas kalbas, kurių nesimokè mokykloje (3 pav.). Statistikos departamento duomenimis, bent vienos užsienio kalbos mokosi $92 \%$ bendrojo lavinimo mokyklų mokinių, o įstojusiujuu i LKA - 98 \%. Iš besimokančiųjų anglų kalbos - mokėsi $87 \%$ mokinių, o LKA - 97 \%; rusų kalbos - nuo 39 iki $41 \%$, o LKA - 3 \% (5 pav.). Vokiečiu kalbos besimokančių asmenų sumažèjo nuo $17 \%$ iki $9 \%$, o LKA - pastaruoju metu nèra tokių stojančiųjų. Prancūzų kalbą renkasi $2 \%$ kariūnų, kai mokykloje net $5 \%$ (žr. 4 pav. ir 5 pav.).

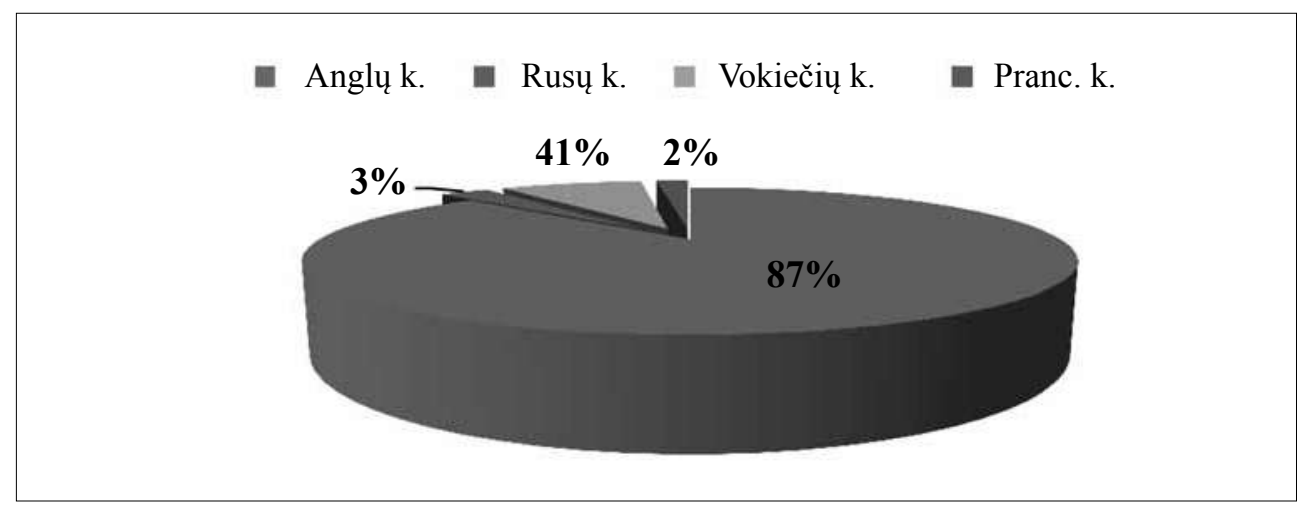

4 pav. Kalbų mokymasis bendrojo lavinimo mokykloje

Dauguma bendrojo lavinimo mokyklų mokinių (96-97 \%) anglų kalbą renkasi kaip pirmają užsienio kalbą ir atitinkamai LKA kariūnai. Rusų kalbą kaip antrają užsienio kalbą renkasi $81 \%$ mokinių ir 83 \% LKA kariūnų (7 pav.).

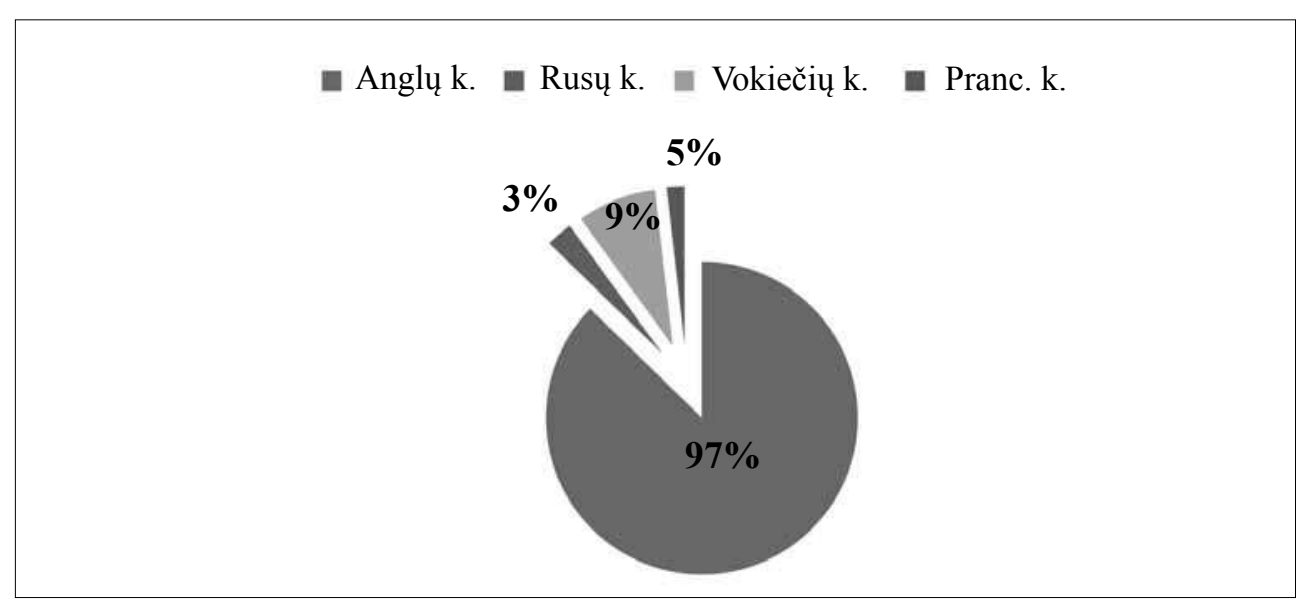

5 pav. LKA kariūnų pasiskirstymas I kurse pagal užsienio kalbų mokymąsi 


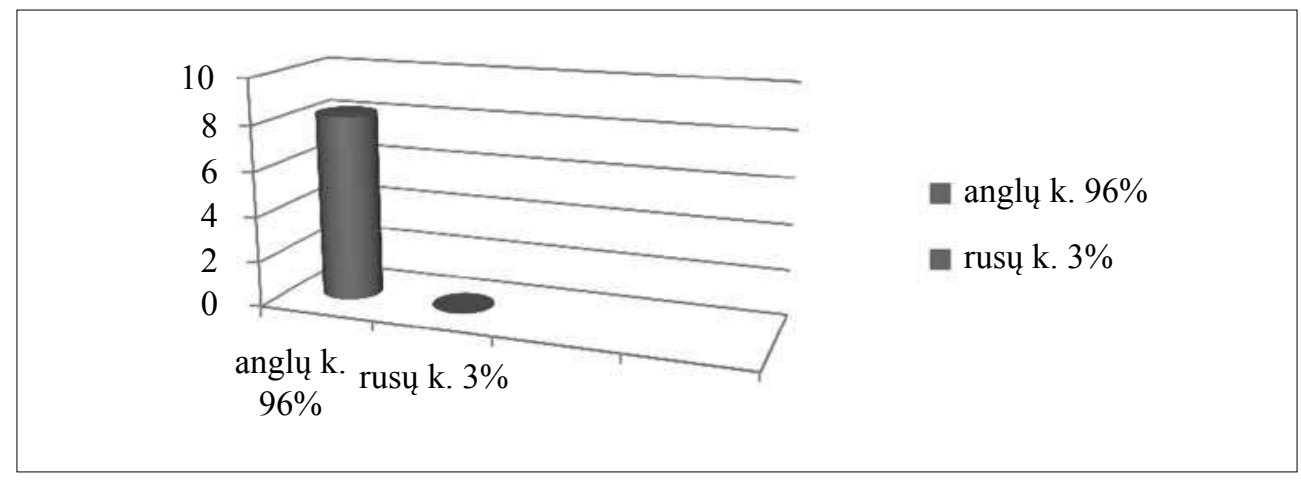

6 pav. Kariūnų pasiskirstymas pagal pirmosios (anglų) ir antrosios (rusų) kalbų mokymąsi

Bendrojo lavinimo mokyklų I ir II užsienio kalbų pasiskirstymas yra atitinkamai $96 \%$ ir $81 \%$ (7 pav.).

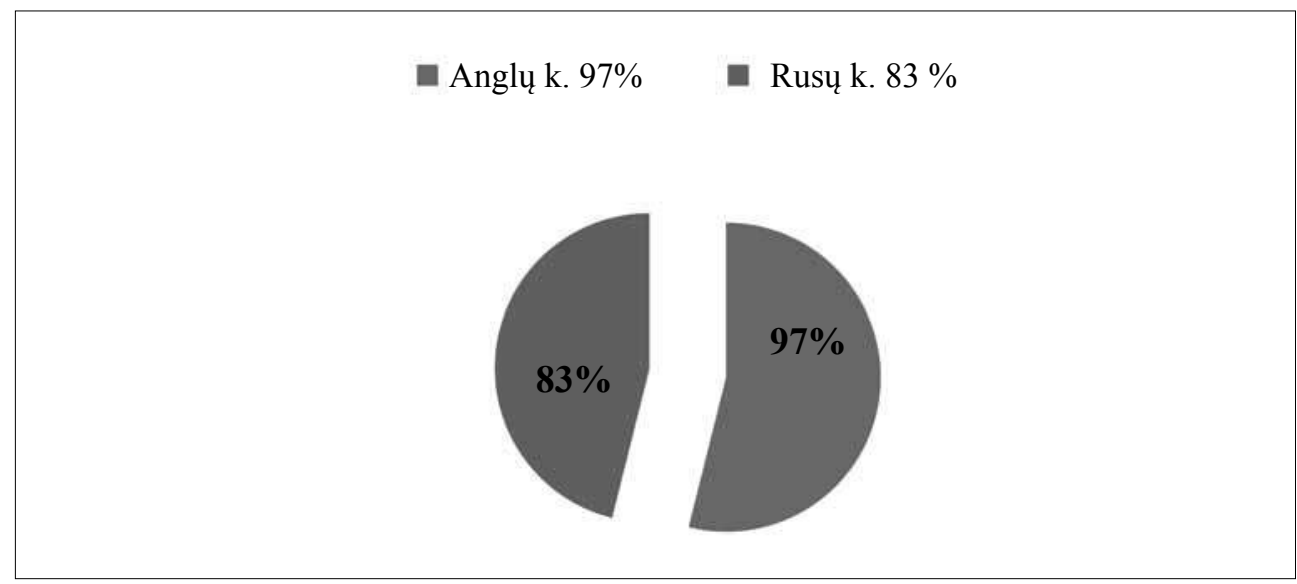

7 pav. I ir II užsienio kalbų pasiskirstymas įstojus ị LKA

Apibendrindami tyrimų rezultatus, galime teigti, jog Lietuvoje besimokančių asmenų užsienio kalbų bendrojo lavinimo mokyklose ir LKA pasirinkimas tiesiogiai koreliuoja. LKA kariūnai dažniausiai renkasi tas užsienio kalbas, kurių jie mokèsi mokykloje. Vos keli kariūnai (1 \%) mokykloje kaip pirmają užsienio kalbą mokèsi rusų ar vokiečių kalbą, o LKA pasirinko tik anglų. Kito pasirinkimo net nèra. Pagal krašto apsaugos ministro ịsakymą (2015 m. liepos 14 d.), paremtą NATO standartais, kariūnas privalo pasiekti anglų kalbos antraji mokèjimo lygị.

Atlikto tyrimo rezultatai ir jų lyginamoji analizè pagal Eurobarometro statistiką parodè, jog absoliuti dauguma besimokančių asmenų užsienio kalbų mokosi planingai ir nepertraukiamai, t. y. mokosi visą gyvenimą. Todèl statistinè dauguma respondentų supranta ir pabrèžia užsienio kalbų svarbą gyvenime ir siekiant karjeros. 
Užsienio kalbos žinios praplečia karininko profesinio bendravimo galimybes, padeda siekti aukštesnio socialinio statuso, kelti kvalifikaciją, tobulèti, pasiruošti savarankiškam gyvenimui po tarnybos, kūrybinei visuomeninei veiklai.

\section{Išvados}

- Mokydama kariūnus, LKA UKK operatyviai reaguoja i naujus iššūkius, vykstančius globalizacijos sąlygomis naujos kalbų mokymo paradigmos virsme, ir sėkmingai sprendžia daugiakalbystès skatinimo problemas.

- UKK turi savo adaptyvų ir efektyvų inovatyvų požiūrị ị užsienio kalbų mokymo ir išmokimo metodologiją, kurị aprobuoja dalyvaudama tarptautinèse NATO ir ES konferencijose ir seminaruose, leisdama mokomąsias knygas, recenzuojamas Lietuvos ir užsienio šalių kalbų specialistų ir ekspertų.

- UKK supranta daugiakalbystę kaip sudètingą vyksmą, kuris reikalauja daug lingvistinių, didaktinių ir psichologinių žinių apie kalbų formavimąsi, kognityvinius jų konstravimosi procesus ir kitų psichinių savybių funkcionavimo svarbą.

- Kariūnų užsienio kalbų mokymosi motyvaciją skatina poreikio svarba, motyvų įvairove ir reikšmingumas asmeniniame individo gyvenime, ji supanti aplinka, mokymosi galimybès.

- Formuojant mokymosi motyvaciją svarbi mokymosi objekto pritaikymo perspektyva - užsienio kalbos praktinis pritaikymas, pavyzdžiui, kai kariūnai turi galimybes vykti ị užsienio šalis pagal „Erasmus“ programą arba pagal karinių aukštujų mokyklų bendradarbiavimo ir mobilumo programas.

- Nuo tinkamai taikomos kalbų mokymo(si) didaktikos priklauso efektyvus ir darnus Lietuvos Krašto apsaugos sistemos funkcionavimas, veiksmingas ịsipareigojimų NATO, ES ir kitiems partneriams vykdymas laiku.

- Anglų kalba tapo darbo kalba ir be II kalbos mokejjimo lygio šiuolaikinis karininkas negali pilnavertiškai ir efektyviai atlikti savo kasdienių pareigų NATO štabuose, logistikos, žvalgybos tarnybose ir kitur.

- Pagrindiniai veiksniai, lemiantys kariūno užsienio kalbų pasirinkimą, yra jo kalbinè patirtis, karjeros perspektyvos ir pastangos (vidiniai bei išoriniai motyvai), kurių gali prireikti mokantis užsienio kalbų.

\section{Literatūra}

1. Butkienè, G.; Kepalaitè, A. (1996). Mokymasis ir asmenybės brendimas. Pedagoginès psichologijos ịvadas studentams, mokytojams, tèvams. Vilnius: Margi raštai.

2. Bitinas, B. (2008). Edukologinis tyrimas: sistema ir procesas. Vilnius: Kronta.

3. Bitinas B. (2002). Pedagoginès diagnostikos pagrindai. Vilnius: Vilniaus pedagoginio universiteto leidykla. 
4. Butkienè, G.; Kepalaite, A. (1996). Mokymas ir asmenybès brendimas. Vilnius: Margi raštai.

5. Deci, E.; Ryan, R. (1985). Intrinsic Motivation and Self-determination in Human Behaviour. New York: Plenum 76 Press.

6. Deci, E., Ryan, R. (1993). Die Selbstbestimmungs theorie der Motivation und ihre Bedeutung für die Pädagogik // Zeitschrift für die Pädagogik, 39. Jg. 1993, Nr. 2, S. 223-238.

7. Dereškevičius, P. (1998). Mokyklos nelankymo priežastys. Sud. P. Dereškevičius, V. Rimkevičienè, V. Targamadzè. Vilnius: Žuvèdra.

8. Fremdsprache Deutsch. Motivation. (2002). Stuttgart: Klett. Fremdsprache Deutsch. Stuttgart.

9. Fremdsprache Deutsch. Motivation. (2002). Stuttgart: Klett.

10. Gage, N. L.; Berliner, D. C. (1994). Pedagoginė psichologija. Vilnius: Alma litera.

11. Gardner, R. C.; Lambert, W. (1972). Attitudes and Motivation in Second Language Learning. Rowley, Mass.: Newbury House.

12. Gardner, R. C.; MacIntyre, P. D. (1993). A Student's Contributions to Second Language Learning. Part II: Affective Variables // Language Teaching, 26, $1-11$.

13. Jovaiša, L. (1993). Pedagogikos terminų žodynas. Kaunas: Šviesa, 1993.

14. Jovaiša, L. (2001). Ugdymo mokslas ir praktika. Analitinių straipsnių monografija.Vilnius.

15. Jovaiša ,L. (1999). Profesinio konsultavimo psichologija. Vilnius, 151 p. ISBN 9986-633-26-5.

16. Jovaiša, L. (2007). Enciklopedinis edukologijos žodynas. Vilnius: Gimtasis žodis.

17. Laužikas, J. 1993. Pedagoginiai raštai. Kaunas: Šviesa.

18. Leitneris, S (1998). Išmokime mokytis. Vilnius. Vaga.

19. Merkys, G. (1999). Testavimas - socialinių mokslų principas. Metodologinio diskurso projekcija.

20. Psichologijos žodynas (1993). Vilnius. Vaga.

21. Socialiniai mokslai (1999). Nr. 2 (19).

22. Rajeckas, V. (1999). Pedagogika - ugdymo mokslas ir menas. Vilnius: VPU leidykla,

23. Rupšienè, L. (1996). Nenoras mokytis - socialinis pedagoginis reiškinys. Klaipeda: Klaipedos universiteto leidykla.

24. Williams, M., and R. L. Burden (1997). Psychology for Language Teachers: A Social Constructive Approach. Cambridge: Cambridge University Press. 


\title{
THE FACTORS DEVELOPING MULTILINGUALISM OF CADETS STUDYING AT THE MAL
}

\author{
Assoc. Prof. Dr. Dileta Jatautaitè \\ The General Jonas Žemaitis Military Academy of Lithuania
}

\section{Summary}

Foreign language learning motivation is an important factor influencing the choice of cadets studying foreign languages at the Military Academy of Lithuania. A foreign language learning is as an object of the learning process in connection with aims, interests and causes - stimuli, which are called learning motives. The article deals with the problems that the detection of which will help to reveal the motives and factors influencing the reasons why cadets choose one or another language.

The MAL offers the choice from the Russian, the English, the German and the French languages. According to the research completed at the Academy, the majority of cadets as well as the majority of Lithuanian school learners (97-96\%) take English for the reason that this language belongs to the most important languages of NATO and EU. It is mandatory for all MAL cadets, especially if they want to be commissioned, to obtain level 2 according to NATO Stanag 6001 requirements. That is why, according to the survey questionnaire, most of the cadets believe that this language will help them climb the career ladder.

The second most significant language was confirmed as Russian. $51 \%$ of cadets treat it as the enemy's language, $37 \%$ think that it is essential in their lives because it is the language of Lithuania's biggest neighbouring country. Meanwhile, $12 \%$ cogitate that it is enough to know just two of them (English and Russian) so that to communicate perfectly well with almost everybody they need in their circle of profession. Thus, good command of language knowledge guarantees the learner to reach his/her objectives and influences successful learning and the quality of knowledge.

In conclusion, learning foreign languages is stimulated and determined by various motives, the value of which is different: some of them are more effective, more powerful for motivation; some are less effective, and have less influence on it.

Each cadet is most affected by the motives that are most relevant to him/her, that usually dominate. In addition, the choice of learning motives should meet social demands, as well as the needs of self-expression and existence. 


\section{AUTORIAUS LYDRAŠTIS}

Autoriaus vardas, pavardè: Dileta Jatautaite

Mokslo laipsnis ir vardas: socialinių mokslų daktarè

Darbo vieta ir pareigos: Generolo Jono Žemaičio Lietuvos karo akademijos Universitetinių studijų instituto Užsienio kalbų katedros vedèja docentė

Autoriaus mokslinių interesų sritys: psicholingvistika, glotoedukologija, edukologija, tradiciniai ir netradiciniai kalbų mokymo metodai ir metodologija, psichoedukologinai kalbų mokymo ir išmokimo pagrindai

Telefonas ir el. pašto adresas: (8 5) 210 3560; dileta.jatautaite@mil.lt

\section{AUTHOR'S COVER LETTER}

Author's name and surname: Dileta Jatautaite

Academic degree and name: Associate Professor, Doctor

Workplace and position: The General Jonas Žemaitis Military Academy of Lithuania, Institute of University Studies, Department of Foreign Languages, Head

Author's research interests: psycholinguistics, glotoeducology, traditional and non-traditional language teaching methods and methodology, psycho-educational basis in language learning and acquisition

Telephone and e-mail address: +370 5210 3560; dileta.jatautaite@mil.lt 